\title{
ANTIMICROBIAL ACTIVITY OF THUJA ORIENTALIS IN COMBINATION WITH CIPROFLOXACIN AGAINST PSEUDOMONAS AERUGINOSA
}

\author{
Hajra Mateen ${ }^{1,2 \otimes}$, Shafiq Ahmad Tariq', \\ Syed Hamid Habib', Syeda Huma Khizar, \\ Abdul Jalil Popalzai, Abid Hussain ${ }^{4}$
}

\begin{abstract}
OBJECTIVE: To compare the combined antimicrobial effect of Thuja orientalis and ciprofloxacin against Pseudomonas aeruginosa in vitro samples.

METHODS: In-vitro antibacterial activity of plant-extracts was evaluated alone and in combination with ciprofloxacin against Pseudomonas aeruginosa using disc-diffusion susceptibility assay (Kirby Bauer method) and minimum inhibitory concentration ( 96 well broth microdilution method) following CLSI guidelines. Pseudomonas aeruginosa clinical strains were collected from Rehman Medical Institute (RMI) and Northwest General Hospital Peshawar, Pakistan and ATCC strains (no.972I) of this bacterium were collected from Agriculture University Peshawar. The organism was tested six times with crude extract and fractionation with different solvents such as n-hexane, chloroform, ethyl acetate and butanol at concentrations of I , 4, 8, I2, 16, 20, 24, 30 and $36 \mathrm{mg} / \mathrm{ml}$. The mean MIC and $\mathrm{FICl}$ (fractional inhibitory concentration index) was obtained to report the synergism. The data were analysed using SPSS version21 .
\end{abstract}

RESULTS: In combination, methanolic crude extract, chloroform and butanol fraction showed synergistic effect at all tested concentrations against Pseudomonas aeruginosa (ATCC $972 \mathrm{I}$ and clinical) except with I, 4, $16 \mathrm{mg} / \mathrm{ml}$ concentrations. Ethyl acetate and aqueous fractions shows indifference and synergistic effect against Pseudomonas aeruginosa (ATCC 972I and clinical) at different concentrations. The fractional inhibitory concentration index $(\mathrm{FICl})$ ranged from 1.24 to 3.24 against Pseudomonas aeruginosa alone and in combination with ciprofloxacin.

CONCLUSION: By disc diffusion method, this study shows synergistic effect against Pseudomonas aeruginosa in combination with ciprofloxacin. However, through minimum inhibitory concentration method, it shows antagonism and indifference but no synergistic effect against different fractions of plant.

KEY WORDS: Drug Resistance, Microbial (MeSH); Drug Resistance (MeSH); Thuja (MeSH); Thuja Orientalis (MeSH); Synergism (Non-MeSH); Fractional Inhibitory Concentration Index (Non-MeSH); Antagonism (Non-MeSH); Microbial Sensitivity Tests (MeSH); Pseudomonas (MeSH); Pseudomonas Infections (MeSH); Pseudomonas aeruginosa (MeSH).

THIS ARTICLE MAY BE CITED AS: Mateen H, Tariq SA, Habib SH, Khizar $\mathrm{SH}$, Popalzia AJ, Hussain A. Antimicrobial activity of Thuja orientalis in combination with ciprofloxacin against Pseudomonas aeruginosa. Khyber Med Univ J 2019; I I(2):90-7. DOI: 10.35845/kmuj.2019.1904 I

\section{INTRODUCTION}

nfectious diseases remain main cause of morbidity and mortality in the developing countries.' New herbal medicines are developed from natural products which make the basis of traditional medicine. ${ }^{2,3}$ In primary
I Institute of Basic Medical Sciences, Khyber Medical University, Peshawar, Pakistan

2 Khyber Medical University Institute of Medical Sciences (KMU-IMS), Kohat, Pakistan

Email凹: hajramatin@gmail.com

3 Rehman Medical College, Peshawar, Pakistan

4 Northwest School of Medicine, Peshawar, Pakistan

Date Submitted:

Date Last Revised:

February 15, 2019

Date Accepted:

June 16,2019

June 20, 2019

health care, approximately $80 \%$ of the population depend on traditional treatments using herbal medicines. ${ }^{4}$ Poor sanitary conditions among the developing countries ${ }^{4}$ and synthetic antimicrobial agents have provoked the development of drug resistant strains among the infectious agents. ${ }^{5}$ In recent years, pharmaceutical companies have developed many antimicrobial drugs, however, bacterial resistance to these drugs is increasing and is now becoming one of the main global problems. ${ }^{5}$ Medicinal plants extracts are important sources for antimicrobial and other sources of new agents that can help in reducing the infection. ${ }^{1,6-8}$ The rationalization of using medicinal plants combined with the existing antimicrobial agents will help in overcoming the bacterial resistance. ${ }^{9,10}$ Furthermore, recently it has been reported that drug synergism can be achieved by mixing antimicrobial agents with plant extracts to yield the desirable results.

Thuja orientalis is a monoecious and evergreen tree belonging to the family Cupresseaceae (Cypress). 'I In traditional medicine, Thuja orientalis is used for treatment of different diseases like bronchial catarrh, enuresis, uterine carcinomas, and rheumatism. ${ }^{12}$ It is also effective in the treatment of psoriasis, amenorrhea, cystitis and worm infestation. ${ }^{12}$ In addition, it has molluscicidal and nematicidal activity. ${ }^{13}$ Leaves of Thuja orientalis produce the essential oil that has its active ingredient "Alpha-thujone" which is effective as anti-fungal and insecticidal agent. ${ }^{13}$ In traditional medicines it is also 
used for the treatment of blood diseases, gastrointestinal symptoms, chronic cough, asthma and skin diseases etc. ${ }^{12}$ Furthermore, the phytochemicals in Thuja orientalis have significant hepatoprotective activity as reported by Dubey and Batra. ${ }^{14,15}$ The different parts of the Thuja orientalis plant are used for different purposes for example leaves are used as antipyretic, anti-diuretic and as astringent. Seeds are used as aperients, laxative, lenitive, sedative and different nervous disorder like insomnia. Scalds and pustules are treated by bark part of the plant. ${ }^{16}$ Pseudomonas aeruginosa is amongst the most common causes of localized suppurative lesions in human beings. Especially in hospital environment, it is capable of developing resistance to fluoroquinolones (e.g. ciprofloxacin) and other antibiotics enhance its importance as human pathogen.

Thuja orientalis have different composition of chemicals among them three substances are very important i.e alpha ( $\alpha$ ) thujaplicin, beta $(\beta)$ thujaplicin and gamma $(\infty)$ thujaplicin. ${ }^{17}$ The bioactive constituents of Thuja orientalis such as saponins, tannins, terpenoids, flavonoids, and alkaloids have great antimicrobial activity. Essential oils of Thuja orientalis also have activity against different viruses like herpes simplex virus type-I (HSVI) and severe acute respiratory syndrome coronavirus (SARSCoronavirus). Looking at the multiple uses of Thuja orientalis we aimed to discover the synergistic effects of Thuja orientalis in combination with ciprofloxacin against Pseudomonas aeruginosa in vitro samples.

\section{METHODS}

Plant Material. Fresh plant leaves were collected from University of Peshawar, Pakistan and washed thoroughly with distilled water, dried for seven days and grinded. The dried powdered leaves were soaked in methanol. The macerated material was kept in dark for 2 weeks at room temperature, shaken vigorously and filtered using Whatman filter paper no.l. In the solid residue fresh methanol was added and the process was repeated three times. In rotatory evaporator the filtered methanolic solution was dried under vacuum pressure below $45^{\circ} \mathrm{C}$. The semi-solid extract was collected and kept in dark for drying in a glass vial at room temperature. The crude extract is divided into two parts. One part is kept as methanolic crude extract ${ }^{18}$ and second part was used for fractionation with different solvents such as nhexane, chloroform, ethyl acetate and butanol in the following way.

I. Methanol crude extract (M.C.E) (EI),

2. N-hexane fraction (E2),

3. Chloroform fraction (E3),

4. Ethyl acetate fraction (E4),

5. Butanol fraction (E5),

6. Aqueous fraction(E6)

Bacterial Isolates Collection Method:

Clinical bacterial isolates were randomly collected from Rehman Medical Institute (RMI) and Northwest General Hospital Peshawar, Pakistan. ATCC strain number 972 I of the bacteria was obtained from The
University of Agriculture, Peshawar. In laminar flow hood all microbial stock culture were streaked on nutrient agar medium plates by using a sterile inoculation loop and incubation at $37^{\circ} \mathrm{C}$ for 24 hours.

\section{Disc Diffusion Susceptibility Assay:}

Extracted samples of Thuja orientalis were tested for antibacterial activity by disc diffusion assay following Clinical and Laboratory Standard Institute (CLSI) guidelines. Nutrient agar media plates were inoculated for 18-24 hours cultures of microbial inoculums. Each disc will represent a separate replication. In the first round of the experiment I mg plant extracts alone in $6 \mu$ ldimethyl sulfoxide (DMSO) and in combination with ciprofloxacin $(50 \mu \mathrm{g})$ will be applied on the discs. In separate petri plates antibiotics as positive control (ciprofloxacin $50 \mu \mathrm{g}$ per $6 \mu \mathrm{l}$ ) and absolute DMSO (6 $\mu \mathrm{l}$ disc $\left.^{-1}\right)$ as negative control will be also applied on the discs incubated at $37^{\circ} \mathrm{C}$ for $18-24$ hours. The zones of inhibition around the discs will be noted next day in $\mathrm{mm}$ by using vernier calipers.

\section{Susceptibility Test Interpretative Criteria for Ciprofloxacin against Pseudomonas aeruginosa by NCCLS (Kirby-Bauer)}

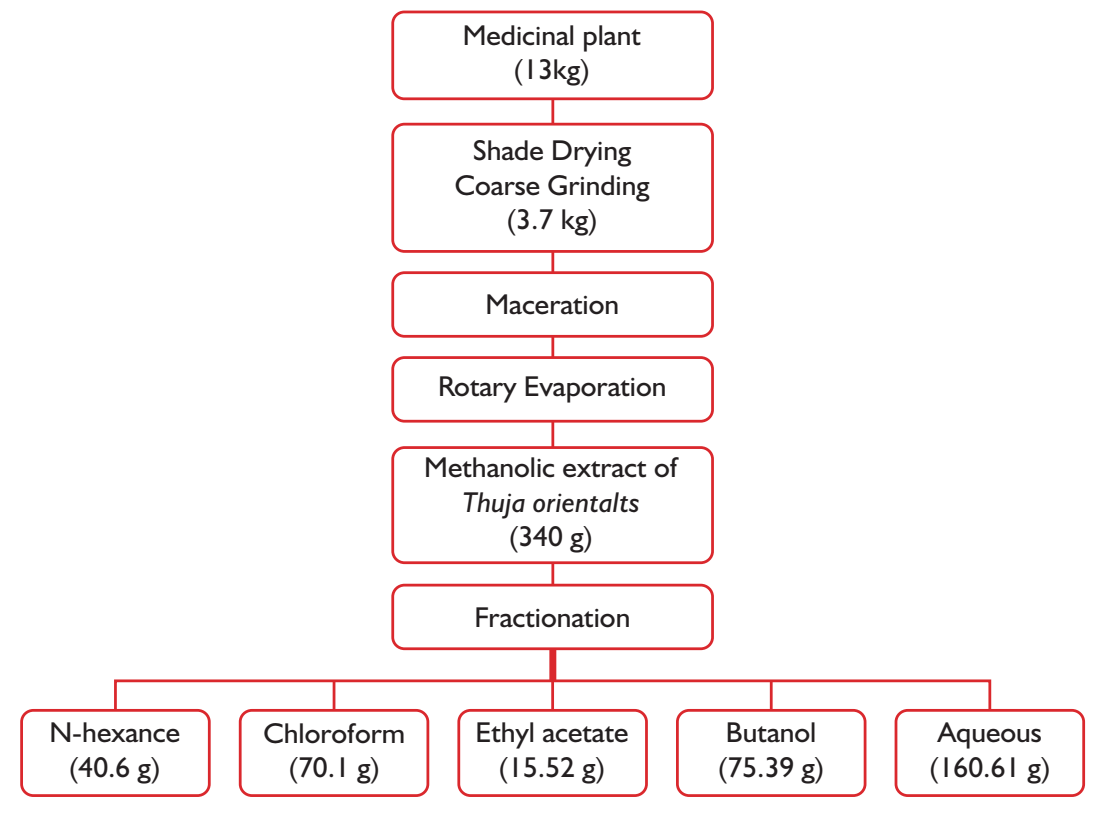

Figure I: Plant Extraction and Fractionation Process 
Bacteria (Pseudomonas aeruginosa) was interpreted as sensitive (zone of inhibition $\geq 2 \mathrm{I}$ ), intermediate (zone of inhibition 16-20) or resistant (zone of inhibition $\leq 15$ ) according to CLSI guidelines of National Committee for Clinical Laboratory Standards (NCCLS). ${ }^{18}$

\section{Minimum inhibitory concentration (MIC)}

After establishing antimicrobial activity through disc diffusion method assay, minimum inhibitory concentration (MIC) was determined by a "broth microdilution method" following CLSI guidelines.

\section{McFarland 0.5 barium sulphate} turbidity standard:

McFarland standard (0.5) was prepared by adding $0.05 \mathrm{ml}$ of barium chloride dihydrate ( $1.175 \%$ $\mathrm{BaCl}_{2} \cdot 2 \mathrm{H}_{2} 0$ ) to $9.95 \mathrm{ml}$ of sulphuric acid $\left(1 \% \mathrm{H}_{2} \mathrm{SO}_{4}\right)$ with constant mixing. Bacterial colonies were transferred to 3-4 $\mathrm{ml}$ of sterile normal saline solution. This inoculum was then matched with 0.5 McFarland standard. Turbidity of inoculum was adjusted by adding more saline solution (to decrease the turbidity) or by adding bacterial growth (to increase turbidity). ${ }^{19}$

\section{6-well Microdilution Tray:}

96-well plates were loaded with $100 \mu \mathrm{l}$ $(0.1 \mathrm{ml})$ of two fold dilutions of extracts into each well. The reconstituted extracts were serially diluted two fold in nutrient broth in order to make different concentrations i.e $24 \mathrm{mg} / \mathrm{ml}$, $12 \mathrm{mg} / \mathrm{ml}, 6 \mathrm{mg} / \mathrm{ml}, 3 \mathrm{mg} / \mathrm{ml}$, I.5 $\mathrm{mg} / \mathrm{ml}, 0.75 \mathrm{mg} / \mathrm{ml}$ and were assayed against the tested microorganism. Each well was filled with $5 \mu \mathrm{l}$ bacterial inoculum $(1.5 \times 105 \mathrm{CFU} / \mathrm{ml})$. Plates without any plant extracts served as growth control. The trays were incubated at $37^{\circ} \mathrm{C}$ for $18-24$ hours. The highest dilution of extract that showed no visible bacterial growth and turbidity was considered as MIC. ${ }^{19}$

\section{Synergistic Antimicrobial Assays}

Subsequently by doing a checkerboard titration, the combination action of both Thuja orientalis extract and ciprofloxacin on each isolate was also studied to assess the synergistic activity. Each organism were tested three times and the mean $\mathrm{MIC}$ and $\mathrm{FICl}$ (fractional inhibitory concentration index) was obtained to report the synergism.

The minimum inhibitory concentration results was interpreted as one of the following categories; synergy; indifference; additive effect or antagonism. ${ }^{20}$

\section{Formula to Determine Synergy (MIC and FIC)}

\begin{tabular}{|c|c|}
\hline$M I C_{A}$ in & $\mathrm{MIC}_{\mathrm{B}}$ in \\
\hline $\mathrm{C}_{\mathrm{A}}{ }_{\mathrm{A}}=$ combination & $\mathrm{FIC}_{\mathrm{B}}=$ combination \\
\hline $\mathrm{MIC}_{\mathrm{A}}$ & MIC \\
\hline
\end{tabular}

Where $A$ and $B$ are the two antimicrobial under investigation.

$\mathrm{FICl}=\mathrm{FIC}_{\mathrm{A}}+\mathrm{FIC}_{\mathrm{B}}$

Mean $\mathrm{FICl} * *$ Sum of $\mathrm{FICl}$ calculated

Number of $\mathrm{FICl}$ calculated

\section{Interpretation}

Synergy = mean $\mathrm{FICl}<0.5$, Partial synergy/addition $=$ mean $\mathrm{FICl}>0.5<$ I.0,

Indifference $=$ mean $\mathrm{FICl}>1-<2.0$, Antagonism $=$ mean $\mathrm{FICl}>2.0$

*FIC: Fractional inhibitory concentration.

**FICI: Fractional inhibitory concentration inde

\section{RESULTS}

The antimicrobial activities of methanolic crude extract (M.C.E) of Thuja orientalis with ciprofloxacin are shown in Table I in which methanol crude extract (EI) showed significant antibacterial activity at different concentrations with mean differences as $(33.66 \pm 0.57,34.66 \pm 0.57$, $35.33 \pm \mathrm{I} .15$ and $36.66 \pm \mathrm{I} .15) \mathrm{mm}$ against the Pseudomonas aeruginosa strain (ATCC 972I). Synergistic effect was observed in means of all tested concentrations with ciprofloxacin against Pseudomonas aeruginosa (ATCC 972I) except at I, 4 and $16 \mathrm{mg} / \mathrm{ml}$. While M.C.E alone exhibited no antibacterial activity against the clinical strain of Pseudomonas aeruginosa at different concentrations but on combination with ciprofloxacin it showed synergistic effect (Table I). However, again at concentrations of $\mathrm{I}$, $4,16 \mathrm{mg} / \mathrm{ml}$ it did not show synergistic effect. The $\mathrm{N}$-hexane fraction (E2) of Thuja orientalis shows no significant antibacterial activity against clinical isolates of Pseudomonas aeruginosa. The N-hexane fraction (E2) of Thuja orientalis showed a significant synergistic activity in combination with ciprofloxacin at different concentrations against Pseudomonas aeruginosa (ATCC 972I). At concentration of $8 \mathrm{mg} / \mathrm{ml}$ an indifference effect was observed with zone of inhibition $28.66 \pm 2.5$ I for both samples. No synergistic activity was found at concentration of I, 4 and 16 $\mathrm{mg} / \mathrm{ml}$ against all tested microorganisms.

The antibacterial activity of chloroform fraction of Thuja orientalis (E3) and its synergistic effect with ciprofloxacin against Pseudomonas aeruginosa strain (ATCC $972 \mathrm{I}$ and clinical) is shown in Table I, the Chloroform fraction of Thuja orientalis showed a synergistic effect with highest zone of inhibition be tween $35.33 \pm 2.52$ to $39.33 \pm 5.5 \mathrm{I}$.Clinical strains shows synergistic effect at different concentration. There is no significant antibacterial activity at I, 4, $16 \mathrm{mg} / \mathrm{ml}$ concentration of chloroform against all tested bacteria.

All tested concentrations of ethyl acetate fraction (E4) shows resistance alone. But in combination it shows synergistic effect at 8 and $12 \mathrm{mg} / \mathrm{ml}$ (clinical strain) and indifference effect at 20 and $30 \mathrm{mg} / \mathrm{ml}$ (ATCC 972I) concentration. In combination butanol fraction (E5) shows synergistic effect at 24 and $30 \mathrm{mg} / \mathrm{ml}$ concentration and shows no antibacterial activity at I, 4, 16 concentrations alone and in combination.

The aqueous fraction of Thuja orientalis (E6) exhibited both synergistic and indifference effects at different concentrations for both ATCC 9721 and clinical strain. 
TABLE II: FRACTIONAL INHIBITORY CONCENTRATION INDEX (FICI) FOR THUJA ORIENTALIS WITH CIPROFLOXACIN AGAINST PSEUDOMONAS AERUGINOSA

\begin{tabular}{|c|c|c|c|c|c|}
\hline \multicolumn{2}{|c|}{ Concentrations } & MIC $_{a}$ & $\mathrm{MIC}_{\mathrm{c}}$ & FIC & $\mathbf{F I C l}$ \\
\hline \multirow{2}{*}{ M.C.E-Cip } & M.C.E. $(\mathrm{mg} / \mathrm{ml})$ & 3 & 6 & 2 & \multirow{2}{*}{2.33} \\
\hline & Cip $(\mu \mathrm{g} / \mathrm{ml})$ & 0.25 & 0.75 & 0.33 & \\
\hline \multirow{2}{*}{ N-Hexane-Cip } & N-hexane $(\mathrm{mg} / \mathrm{ml})$ & 6 & 3 & 0.5 & \multirow{2}{*}{1.24} \\
\hline & Cip $(\mu \mathrm{g} / \mathrm{ml})$ & 0.25 & 0.187 & 0.74 & \\
\hline \multirow{2}{*}{ Chloroform-Cip } & Chloroform (mg/ml) & 6 & 3 & 0.5 & \multirow{2}{*}{2} \\
\hline & Cip $(\mu \mathrm{g} / \mathrm{ml})$ & 0.25 & 0.375 & 1.5 & \\
\hline \multirow{2}{*}{ E.A-Cip } & $\mathrm{E} . \mathrm{A}(\mathrm{mg} / \mathrm{ml})$ & 3 & 3 & $\mathrm{I}$ & \multirow{2}{*}{1.74} \\
\hline & Cip $(\mu \mathrm{g} / \mathrm{ml})$ & 0.25 & 0.187 & 0.74 & \\
\hline \multirow{2}{*}{ Butanol-Cip } & Butanol $(\mathrm{mg} / \mathrm{ml})$ & 6 & 1.5 & 0.25 & \multirow{2}{*}{3.25} \\
\hline & Cip $(\mu \mathrm{g} / \mathrm{ml})$ & 0.25 & 0.75 & 3 & \\
\hline \multirow{2}{*}{ Aqueous Cip } & Auqeous $(\mathrm{mg} / \mathrm{ml})$ & No MIC & 1.5 & 1.5 & \multirow{2}{*}{2.24} \\
\hline & Cip $(\mu \mathrm{g} / \mathrm{ml})$ & 0.25 & 0.187 & 0.74 & \\
\hline
\end{tabular}

Evaluation of Synergistic effect of ciprofloxacin / extracts

Interactions of antimicrobial agents and Thuja orientalis plant in different mediums of extract showed indifferent or antagonistic effect as no significant reduction in MIC of the tested antibiotics against Pseudomonas aeruginosa was observed as evident from Table II.

\section{DISCUSSION}

The main aim of the study was to study the synergistic activity of plant extract with the use of antibiotics in order to enhance the effectiveness of antibiotics against multidrug resistance bacteria. Antimicrobial agents are the important drugs to counter infectious diseases, however, distinct characteristic of microbes and pathogens cause development of resistance with time. This is decreasing the effectiveness of the antibiotics against certain pathogen; thus, posing a serious threat to health of the individuals. ${ }^{20}$ Evaluation to use medicinal plant extracts and their essential oils with synthetic medicines and antibiotics have been carried out in various parts of the world with varied results. Study carried out by Moussaoui and Alaoui showed that all tested bacteria are sensitive to five essential oils of medicinal plants except Pseudomonas aeruginosa. ${ }^{21}$ This is also observed from our results showing a zone of inhibition of Thuja orientalis alone and is also supplemented in previous studies. However, the combined effect with ciprofloxacin along with Thuja orientalis has indicated that synergism at certain concentrations can be achieved and may be effective for resistant strains such as Pseudomonas aeruginosa. Khadir et al. observe similar findings that Pseudomonas aeruginosa resisted the action of the essential oil of Thymus lanceolatus. ${ }^{21}$

Medicinal plants have long been an important source of medicinal agents. The rationalization of using medicinal plants combined with the existing antimicrobial agents is an effective method to overcome resistance. Simultaneous administration of two or more drugs or an antibiotic with a medicinal plant has shown to provide effective treatment for the resistant pathogens. Drug synergism between known antimicrobial agents and bioactive plant extracts is a novel concept, recently reported to yield some desirable results. Thuja orientalis commonly known as Pankh, is an evergreen, monoecious tree or shrub. It is an important plant ever since medieval ages due to its multiple reported medicinal value due to the presence of one or more of the active constituents. Many researches have shown that Thuja orientalis has significant antibacterial, anti-fungal, anti-viral, anti-inflammatory, anticancer, larvicidal, insecticidal, nematicidal and anti-oxidant activities. ${ }^{22}$ Pseudomonas aeruginosa is amongst the most common causes of localized suppurative lesions in humans, especially in hospitals. Furthermore, their ability to develop resistance to fluoroquinolones makes their treatment a major problem. ${ }^{23}$

In this study, medicinal effects of Thuja orientalis were evaluated independently and in combination with ciprofloxacin. In order to discover a better solution for increasing the effectiveness of concerned antibiotic under study, six extracts in various organic and aqueous solvent were obtained and evaluated for comparison. Disk diffusion susceptibility assay method was employed and different concentrations were tested. MIC of Thuja orientalis ciprofloxacin for Pseudomonas aeruginosa were separately obtained as standard and checked against MIC of combination of Thuja orientalis and ciprofloxacin. The results of check board studies of the fractions of Thuja orientalis with ciprofloxacin combination are indicated in Table I and II. Mean $\mathrm{FICl}$ calculated for all fractions of Thuja orientalis for Pseudomonas aeruginosa showed antagonism as mean $\mathrm{FICl}$ was around 2. I 3 (>2). Synergistic FICl values were not observed with any of the strains. Interactions of antimicrobial agents and Thuja orientalis plant in different mediums/fractions of extract showed indifferent or antagonistic effect, as there was no significant reduction in MIC of the tested antibiotics against Pseudomonas aeruginosa. Although, at varied level of concentrations in various fractions of methanolic, $\mathrm{N}$ hexane, chloroform, ethyl acetate, butanol and aqueous fraction, synergism was observed. However, the observations remained below the deduced synergistic effects; thereby validation of synergistic effect of Thuja orientalis with ciprofloxacin remained doubtful. Similar findings were observed by Kim and Choi by using Thuja orientalis extract with different antibiotics. $^{13}$

Although the results of observations of various fractions and calculated MIC did not support the synergistic administration of extract of Thuja orientalis with ciprofloxacin, nevertheless, it does not close the window of opportunity here, as combination with other antimicrobial 
ANTIMICROBIAL ACTIVITY OF THUJA ORIENTALIS IN COMBINATION WITH CIPROFLOXACIN AGAINST PSEUDOMONAS AERUGINOSA

TABLE I: ANTIMICROBIAL ACTIVITY OF DIFFERENT FRACTIONS OF THUJA ORIENTALIS AND ITS SYNERGISTIC EFFECT WITH CIPROFLOXACIN

\begin{tabular}{|c|c|c|c|c|c|c|}
\hline Fractions & Microorganism & Conc. $(\mathrm{mg} / \mathrm{ml})$ & Zone of Inhibition (mm) & Stnd. Cip. Disc & T.O \& Cip & Zone of Inhibition (mm) \\
\hline \multirow{18}{*}{ EI } & \multirow{9}{*}{$\begin{array}{l}\text { P. aeruginosa } \\
\text { (ATCC 972I) }\end{array}$} & 01 & $0.33 \pm 0.57$ & $28.33 \pm 0.57$ & I + cip & $0.00 \pm 0.00$ \\
\hline & & 04 & $0.33 \pm 0.57$ & $28.33 \pm 0.57$ & 4+cip & $0.00 \pm 0.00$ \\
\hline & & 08 & $15.33 \pm 0.57$ & $28.33 \pm 0.57$ & $8+$ cip & $33.66 \pm 0.57$ \\
\hline & & 12 & $16.33 \pm 0.57$ & $28.33 \pm 0.57$ & $12+$ cip & $34.66 \pm 0.57$ \\
\hline & & 16 & $0.33 \pm 0.57$ & $28.66 \pm 0.57$ & $16+$ cip & $0.33 \pm 0.57$ \\
\hline & & 20 & $16.33 \pm 0.57$ & $28.66 \pm 0.57$ & $20+$ cip & $34.66 \pm 1.15$ \\
\hline & & 24 & $17.33 \pm 0.57$ & $28.66 \pm 0.57$ & $24+$ cip & $36.66 \pm 1.15$ \\
\hline & & 30 & $17.66 \pm 0.57$ & $27.66 \pm 1.52$ & $30+$ cip & $34 \pm 1$ \\
\hline & & 36 & $19 \pm 1$ & $27.66 \pm 1.52$ & $36+$ cip & $35.33 \pm 1.15$ \\
\hline & \multirow{9}{*}{$\begin{array}{l}\text { P. aeruginosa } \\
\text { (Clinical) }\end{array}$} & 0I & $0.66 \pm 0.01$ & $28.33 \pm 1.52$ & I +cip & $0.33 \pm 0.57$ \\
\hline & & 04 & $0.00 \pm 0.01$ & $28.33 \pm 1.52$ & $4+$ cip & $0.00 \pm 0.01$ \\
\hline & & 08 & $0.33 \pm 0.57$ & $28.33 \pm 1.52$ & $8+$ cip & $41 \pm 1$ \\
\hline & & 12 & $7.66 \pm 4.93$ & $28.66 \pm 0.57$ & $12+$ cip & $41.33 \pm 1.15$ \\
\hline & & 16 & $0.01 \pm 0.06$ & $28.66 \pm 0.57$ & $16+$ cip & $0.33 \pm 0.57$ \\
\hline & & 20 & $8 \pm 3.46$ & $28.66 \pm 0.57$ & $20+$ cip & $34.66 \pm 1.15$ \\
\hline & & 24 & $11.33 \pm 4.72$ & $28.66 \pm 0.57$ & $24+$ cip & $36.66 \pm 1.15$ \\
\hline & & 30 & $9.66 \pm 6.35$ & $28 \pm 2$ & $30+$ cip & $34 \pm 1$ \\
\hline & & 36 & $9.33 \pm 5.77$ & $28 \pm 2$ & $36+$ cip & $35.33 \pm 1.15$ \\
\hline \multirow{18}{*}{ E2 } & \multirow{9}{*}{$\begin{array}{l}\text { P. aeruginosa } \\
\text { (ATCC 972I) }\end{array}$} & 01 & $0.00 \pm 0.00$ & $27.66 \pm 1.15$ & I +cip & $0.00 \pm 0.00$ \\
\hline & & 04 & $0.00 \pm 0.00$ & $27.66 \pm 1.15$ & $4+$ cip & $0.00 \pm 0.00$ \\
\hline & & 08 & $12.66 \pm 1.52$ & $27.66 \pm 1.15$ & $8+$ cip & $28.66 \pm 2.51$ \\
\hline & & 12 & $14.66 \pm 1.15$ & $27.66 \pm 1.15$ & $12+$ cip & $30 \pm 3.60$ \\
\hline & & 16 & $0.66 \pm 0.57$ & $27.66 \pm 0.57$ & $16+$ cip & $0.00 \pm 0.00$ \\
\hline & & 20 & $15.66 \pm 0.57$ & $27.66 \pm 0.57$ & $20+$ cip & $32 \pm 1$ \\
\hline & & 24 & $16.66 \pm 0.57$ & $27.66 \pm 0.57$ & $24+$ cip & $33 \pm 1$ \\
\hline & & 30 & $17.66 \pm 0.57$ & $28 \pm 1$ & $30+$ cip & $36 \pm I$ \\
\hline & & 36 & $18.66 \pm 0.57$ & $28 \pm 1$ & $36+$ cip & $37 \pm 1$ \\
\hline & \multirow{9}{*}{$\begin{array}{l}\text { P. aeruginosa } \\
\text { (Clinical) }\end{array}$} & 01 & $0.00 \pm 0.06$ & $27.66 \pm 0.57$ & I+cip & $0.00 \pm 0.00$ \\
\hline & & 04 & $0.00 \pm 0.00$ & $27.66 \pm 0.57$ & $4+$ cip & $0.00 \pm 0.00$ \\
\hline & & 08 & $2.66 \pm 1.52$ & $27.66 \pm 0.57$ & $8+$ cip & $28.66 \pm 2.51$ \\
\hline & & 12 & $14.66 \pm 1.15$ & $27.66 \pm 0.57$ & $12+$ cip & $30 \pm 3.60$ \\
\hline & & 16 & $0.02 \pm 0.88$ & $27.66 \pm 0.57$ & $16+$ cip & $0.00 \pm 0.00$ \\
\hline & & 20 & $8 \pm 3.21$ & $27.66 \pm 0.57$ & $20+$ cip & $32 \pm 1$ \\
\hline & & 24 & $8 \pm 3.21$ & $27.66 \pm 0.57$ & $24+$ cip & $33 \pm 1$ \\
\hline & & 30 & $9 \pm 4.35$ & $27.66 \pm 0.57$ & $30+$ cip & $36 \pm 1$ \\
\hline & & 36 & $9 \pm 6.35$ & $27.66 \pm 0.57$ & $36+$ cip & $37 \pm 1$ \\
\hline \multirow{18}{*}{ E3 } & \multirow{9}{*}{$\begin{array}{l}\text { P. aeruginosa } \\
\text { (ATCC 972I) }\end{array}$} & 01 & $0.33 \pm 0.00$ & $28.33 \pm 0.58$ & I +cip & $0.00 \pm 0.00$ \\
\hline & & 04 & $0.30 \pm 0.00$ & $28.33 \pm 0.58$ & $4+$ cip & $0.00 \pm 0.00$ \\
\hline & & 08 & $14.67 \pm 1.15$ & $28.33 \pm 0.58$ & $8+$ cip & $35.33 \pm 2.52$ \\
\hline & & 12 & $14.67 \pm 1.15$ & $28.33 \pm 0.58$ & $12+$ cip & $37.33 \pm 2.03$ \\
\hline & & 16 & $0.00 \pm 1.00$ & $28.33 \pm 0.58$ & $16+$ cip & $0.00 \pm 0.00$ \\
\hline & & 20 & $19.00 \pm 1.00$ & $28.33 \pm 0.58$ & $20+$ cip & $37.00 \pm 4.58$ \\
\hline & & 24 & $21.00 \pm 1.00$ & $28.33 \pm 0.58$ & $24+$ cip & $39.00 \pm 3.61$ \\
\hline & & 30 & $|9.67 \pm 3.5|$ & $27.67 \pm 2.31$ & $30+$ cip & $37.67 \pm 5.13$ \\
\hline & & 36 & $20.33 \pm 3.06$ & $27.67 \pm 2.31$ & $36+$ cip & $39.33 \pm 5.51$ \\
\hline & \multirow{9}{*}{$\begin{array}{l}\text { P. aeruginosa } \\
\text { (Clinical) }\end{array}$} & 01 & $0.00 \pm 1.00$ & $28.67 \pm 0.58$ & I +cip & $0.00 \pm 0.00$ \\
\hline & & 04 & $0.33 \pm 0.58$ & $28.67 \pm 0.58$ & $4+$ cip & $0.00 \pm 0.00$ \\
\hline & & 08 & $7.33 \pm 2.31$ & $28.67 \pm 0.58$ & $8+$ cip & $31.00 \pm 1.00$ \\
\hline & & 12 & $9.00 \pm 2.65$ & $28.67 \pm 0.58$ & $12+$ cip & $31.33 \pm 2.52$ \\
\hline & & 16 & $0.67 \pm 0.89$ & $27.67 \pm 0.58$ & $16+$ cip & $0.00 \pm 0.00$ \\
\hline & & 20 & $9.00 \pm 3.61$ & $27.67 \pm 0.58$ & $20+$ cip & $30.00 \pm 1.00$ \\
\hline & & 24 & $7.00 \pm 2.00$ & $27.67 \pm 0.58$ & $24+$ cip & $31.00 \pm 1.00$ \\
\hline & & 30 & $9.00 \pm 3.00$ & $27.67 \pm 1.53$ & $30+$ cip & $31.00 \pm 1.00$ \\
\hline & & 36 & $8.33 \pm 4.04$ & $27.67 \pm 1.53$ & $36+$ cip & $31.00 \pm 1.00$ \\
\hline
\end{tabular}


ANTIMICROBIAL ACTIVITY OF THUJA ORIENTALIS IN COMBINATION WITH CIPROFLOXACIN AGAINST PSEUDOMONAS AERUGINOSA

\begin{tabular}{|c|c|c|c|c|c|c|}
\hline \multirow{18}{*}{ E4 } & \multirow{9}{*}{$\begin{array}{l}\text { P. aeruginosa } \\
\text { (ATCC 972I) }\end{array}$} & 01 & $0.00 \pm 0.00$ & $28.00 \pm 0.00$ & $I+$ cip & $0.00 \pm 0.00$ \\
\hline & & 04 & $0.00 \pm 0.02$ & $28.00 \pm 0.00$ & $4+$ cip & $0.00 \pm 0.00$ \\
\hline & & 08 & $9.67 \pm 6.35$ & $28.00 \pm 0.00$ & $8+$ cip & $27.00 \pm 3.61$ \\
\hline & & 12 & $10 \pm 6.93$ & $28.00 \pm 0.00$ & $12+$ cip & $28.33 \pm 4.04$ \\
\hline & & 16 & $0 \pm 0.05$ & $28.67 \pm 0.58$ & $16+$ cip & $0.00 \pm 0.00$ \\
\hline & & 20 & $7.67 \pm 4.93$ & $28.67 \pm 0.58$ & $20+$ cip & $30.67 \pm 0.58$ \\
\hline & & 24 & $6.67 \pm 6.43$ & $28.67 \pm 0.58$ & $24+$ cip & $31.67 \pm 0.58$ \\
\hline & & 30 & $6.33 \pm 5.5 \mathrm{I}$ & $27.67 \pm 0.58$ & $30+$ cip & $29.00 \pm 1.00$ \\
\hline & & 36 & $6.33 \pm 5.5 \mathrm{I}$ & $27.67 \pm 0.58$ & $36+$ cip & $30.00 \pm 1.00$ \\
\hline & \multirow{9}{*}{$\begin{array}{l}\text { P. aeruginosa } \\
\text { (Clinical) }\end{array}$} & 01 & $000 \pm 0.00$ & $28.00 \pm 0.00$ & I+cip & $0.00 \pm 0.00$ \\
\hline & & 04 & $0.33 \pm 0.01$ & $28.00 \pm 0.00$ & $4+$ cip & $0.00 \pm 0.00$ \\
\hline & & 08 & $6.33 \pm 7.5 \mathrm{I}$ & $28.00 \pm 0.00$ & $8+$ cip & $31.33 \pm 4.16$ \\
\hline & & 12 & $6.67 \pm 8.08$ & $28.00 \pm 0.00$ & $12+$ cip & $31.67 \pm 6.66$ \\
\hline & & 16 & $0.33 \pm 0.58$ & $28.33 \pm 0.58$ & $16+$ cip & $0.00 \pm 0.00$ \\
\hline & & 20 & $11.67 \pm 0.58$ & $28.33 \pm 0.58$ & $20+$ cip & $30.33 \pm 0.58$ \\
\hline & & 24 & $12.67 \pm 0.58$ & $28.33 \pm 0.58$ & $24+$ cip & $31.67 \pm 0.58$ \\
\hline & & 30 & $12.33 \pm 0.58$ & $28.00 \pm 1.00$ & $30+$ cip & $29.33 \pm 0.58$ \\
\hline & & 36 & $13.33 \pm 0.58$ & $28.00 \pm 1.00$ & $36+$ cip & $31.33 \pm 0.58$ \\
\hline \multirow{18}{*}{ E5 } & \multirow{9}{*}{$\begin{array}{l}\text { P. aeruginosa } \\
\text { (ATCC 972I) }\end{array}$} & 01 & $0.00 \pm 0.00$ & $28.00 \pm 1.00$ & $I+$ cip & $0.00 \pm 0.00$ \\
\hline & & 04 & $0.00 \pm 0.00$ & $28.00 \pm 1.00$ & $4+$ cip & $0.00 \pm 0.00$ \\
\hline & & 08 & $6.00 \pm 5.20$ & $28.00 \pm 1.00$ & $8+$ cip & $32.67 \pm 3.79$ \\
\hline & & 12 & $6.33 \pm 7.5 \mathrm{I}$ & $28.00 \pm 1.00$ & $12+$ cip & $32.33 \pm 6.66$ \\
\hline & & 16 & $0.00 \pm 0.00$ & $27.33 \pm 0.58$ & $16+$ cip & $0.00 \pm 0.00$ \\
\hline & & 20 & $11.00 \pm 1.00$ & $27.33 \pm 0.58$ & $20+$ cip & $31.00 \pm 1.00$ \\
\hline & & 24 & $13.00 \pm 1.00$ & $27.33 \pm 0.58$ & $24+$ cip & $33.00 \pm 1.00$ \\
\hline & & 30 & $13.67 \pm 0.58$ & $27.33 \pm 0.58$ & $30+$ cip & $30.00 \pm 1.00$ \\
\hline & & 36 & $14.67 \pm 0.58$ & $27.33 \pm 0.58$ & $36+$ cip & $31.67 \pm 1.53$ \\
\hline & \multirow{9}{*}{$\begin{array}{l}\text { P. aeruginosa } \\
\text { (Clinical) }\end{array}$} & 01 & $0.00 \pm 0.00$ & $28.33 \pm 1.53$ & I+cip & $0.00 \pm 0.00$ \\
\hline & & 04 & $0.33 \pm 0.04$ & $28.33 \pm 1.53$ & $4+$ cip & $0.00 \pm 0.00$ \\
\hline & & 08 & $6.00 \pm 5.20$ & $28.33 \pm 1.53$ & $8+$ cip & $25.67 \pm 5.13$ \\
\hline & & 12 & $6.33 \pm 7.5 \mathrm{I}$ & $28.33 \pm 1.53$ & $12+$ cip & $29.00 \pm 2.65$ \\
\hline & & 16 & $0.01 \pm 0.05$ & $27.33 \pm 0.58$ & $16+$ cip & $0.00 \pm 0.00$ \\
\hline & & 20 & $6.67 \pm 4.5$ I & $27.33 \pm 0.58$ & $20+$ cip & $29.00 \pm 1.00$ \\
\hline & & 24 & $7.67 \pm 5.5 \mathrm{I}$ & $27.33 \pm 0.58$ & $24+$ cip & $30.00 \pm 1.00$ \\
\hline & & 30 & $6.33 \pm 5.77$ & $27.33 \pm 0.58$ & $30+$ cip & $30.00 \pm 1.00$ \\
\hline & & 36 & $\mathrm{II} \pm 5.5 \mathrm{I}$ & $27.33 \pm 0.58$ & $36+$ cip & $29.67 \pm 1.15$ \\
\hline \multirow{18}{*}{ E6 } & \multirow{9}{*}{$\begin{array}{l}\text { P. aeruginosa } \\
\text { (ATCC 972I) }\end{array}$} & 01 & $0.00 \pm 0.00$ & $27.67 \pm 0.58$ & $I+$ cip & $0.00 \pm 0.00$ \\
\hline & & 04 & $0.00 \pm 0.00$ & $27.67 \pm 0.58$ & $4+$ cip & $0.00 \pm 0.00$ \\
\hline & & 08 & $0.00 \pm 0.00$ & $27.67 \pm 0.58$ & $8+$ cip & $29.00 \pm 1.00$ \\
\hline & & 12 & $8 \pm 2.08$ & $27.67 \pm 0.58$ & $12+$ cip & $30.00 \pm 1.00$ \\
\hline & & 16 & $0.00 \pm 0.00$ & $28.33 \pm 0.58$ & $16+$ cip & $0.00 \pm 0.00$ \\
\hline & & 20 & $0.00 \pm 0.00$ & $28.33 \pm 0.58$ & $20+$ cip & $39.33 \pm 0.58$ \\
\hline & & 24 & $8 \pm 4.04$ & $28.33 \pm 0.58$ & $24+$ cip & $29.33 \pm 1.15$ \\
\hline & & 30 & $8.67 \pm 1.53$ & $27.33 \pm 2.08$ & $30+$ cip & $30.00 \pm 1.00$ \\
\hline & & 36 & $6.67 \pm 5.86$ & $27.33 \pm 2.08$ & $36+$ cip & $30.33 \pm 1.15$ \\
\hline & \multirow{9}{*}{$\begin{array}{l}\text { P. aeruginosa } \\
\text { (Clinical) }\end{array}$} & 01 & $0.67 \pm 0.58$ & $27.33 \pm 1.15$ & I +cip & $0.00 \pm 0.00$ \\
\hline & & 04 & $0.67 \pm 0.58$ & $27.33 \pm 1.15$ & $4+$ cip & $0.00 \pm 0.00$ \\
\hline & & 08 & $9 \pm 5.20$ & $27.33 \pm 1.15$ & $8+$ cip & $35.00 \pm 2.65$ \\
\hline & & 12 & $9 \pm 5.73$ & $27.33 \pm 1.15$ & $12+$ cip & $37.00 \pm 1.73$ \\
\hline & & 16 & $0.00 \pm 0.00$ & $28.00 \pm 1.00$ & $16+$ cip & $0.00 \pm 0.00$ \\
\hline & & 20 & $11.00 \pm 1.00$ & $28.00 \pm 1.00$ & $20+$ cip & $30.67 \pm 0.58$ \\
\hline & & 24 & $12.00 \pm 1.00$ & $28.00 \pm 1.00$ & $24+$ cip & $31.67 \pm 0.58$ \\
\hline & & 30 & $12.67 \pm 0.58$ & $28.00 \pm 1.00$ & $30+$ cip & $30.67 \pm 1.15$ \\
\hline & & 36 & $13.67 \pm 0.58$ & $28.00 \pm 1.00$ & $36+$ cip & $32.33 \pm 1.15$ \\
\hline
\end{tabular}


agents is a vast avenue, which can be explored in search for right grouping against resistance pathogens. Importance of identifying new and effective antimicrobial agents along with the value of medicinal plants helps reduce the use of antibiotics against resistant strains in clinical practice. This particular study observed synergism of Thuja orientalis with ciprofloxacin, however, the effects were nonsignificant. These needs to be further explored with different extraction methods and other medicinal plants in combination for effective synergism to anti-microbial drugs.

\section{CONCLUSION}

By disc diffusion method, this study shows synergistic effect against Pseudomonas aeruginosa in combination with ciprofloxacin. However, through minimum inhibitory concentration method, it shows antagonism and indifference but no synergistic effect against different fractions of plant.

\section{REFERENCES}

I. Betoni JE, Mantovani RP, Barbosa LN, Di Stasi LC, Fernandes Junior A. Synergism between plant extract and antimicrobial drugs used on Staphylococcus aureus diseases. Mem Inst Oswaldo Cruz 2006 Jun; IOI (4):387-90. DOI: I $0.1590 /$ s0074-0276200 6000400007.

2. Cragg GM, Newman DJ. Natural products: a continuing source of novel drug leads. Biochim Biophys Acta 2013 Jun; I830(6):3670-95. DOI: $10.1016 / \mathrm{j} . \mathrm{bbagen}$. 2013.02.008.

3. Newman DJ, Cragg GM, Snader $K M$. The influence of natural products upon drug discovery. Nat Prod Rep 2000 Jun; I7(3):2। 5-34. DOI: 10.1039/A902202C.

4. Nath K, Bloomfield S, Pellegrini S, Beumer R, Exner M, Scott E, et al. Home hygiene and the prevention of infectious disease in developing countries: a responsibility for all. Int J Environ Health Res 2003 Jun; 13 Suppl I:S5-8. DOI:I0.1080/
$09603|203| 000102750$.

5. Rahman BA, Wasfy MO, Maksoud MA, Hanna N, Dueger E, House B. Multi-drug resistance and reduced susceptibility to ciprofloxacin among Salmonella enterica serovar Typhi isolates from the Middle East and Central Asia. New Microbes New Infect 2014 Jul;2(4):88-92. DOI: I0.1002/nmi2.46.

6. Brighenti FL, Salvador MJ, Delbem $A C B$, Delbem ACB, Oliveira MA, Soares $C P$, et al. Systematic screening of plant extracts from the Brazilian Pantanal with antimicrobial activity against bacteria with cariogenic relevance. Caries Res 2014;48(5): 353-60. DOI: I0.II59/000357225

7. Lairungruang $\mathrm{K}$, Itharat $\mathrm{A}$, Panthong S. Antimicrobial activity of extracts from a Thai traditional remedy called Kabpi for oral and throat infection and its plant components. J Med Assoc Thai 2014 Aug;97 Suppl 8:SI08-I5.

8. Mwambete KD. The in vitro antimicrobial activity of fruit and leaf crude extracts of Momordica charantia: a Tanzania medicinal plant. Afr Health Sci 2009 Mar;9(I):34-9.

9. Castello MC, Phatak A, Chandra N, Sharon M. Antimicrobial activity of crude extracts from plant parts and corresponding calli of Bixa orellana L. Indian J Exp Biol 2002 Dec;40( I 2): |378-8| .

10. You YO, Choi NY, Kang SY, Kim KJ. Antibacterial Activity of Rhus javanica against MethicillinResistant Staphylococcus aureus. Evid Based Complement Alternat Med 2013;2013:549207. DOI: I0.1I55/2013/549207.

II.Anonymous. Plants for future; Thuja oriental-L. [Cited on: April 10, 2019]. Available from URL: http://www. pfaf.org/user/ Plant.aspx? LatinName $=$ Thuja + ori ental.

12. Biswas R, Mandal SK, Dutta S, Bhattacharyya SS, Boujedaini N, Khuda-Bukhsh AR. Thujone-Rich Fraction of Thuja occidentalis
Demonstrates Major Anti-Cancer Potentials: Evidences from In Vitro Studies on A375 Cells. Evid Based Complement Alternat Med 20 I ;20 I I:568।48. DOI: I0.1093/ ecam/neq042.

13. Kim CS, Choi SU, Lee KR. Three new diterpenoids from the leaves of Thuja orientalis. Planta Med 20I 2;78(5):485-7. DOI: 10.1055/s$003|-| 2982 \mid 5$.

14. D u b e y S K, B a t r a A. Hepatoprotective activity from ethanol fraction of Thuja occidentalis Linn. Asian J Res Chem 2008; I (I):32-5.

15. Dubey SK, Batra A. Antioxidant activity of Thuja occidentalis Linn. Asian J Pharm Clin Res 2009; I (2):73-6

16. Srivastava P, Kumar P, Singh DK, Singh VK. Biological Properties of Thuja orientalis Linn. Advan Life Sci 20I2;2(2):I7-20. DOI: I0.5923/ j.als.20120202.04

17. Dwivedi SC, Shekhawat NB. Repellent effect of some indigenous plant extract against Trogoderma granarium (Everts). Asian JExp Sci 2004; I8(I):47-5I .

18. Moussaoui F, Alaoui T. Evaluation of antibacterial activity and synergistic effect between antibiotics and the essential oils of some medicinal plants. Asian Pac J Trop Med 20I6;6(I):32-7. DOI: 10.10I6/ j.apjtb.20I5.09.024

19. Shinwari ZK, Malik S, Karim AM, Faisal R, Qaiser M. Biological activities of commonly used medicinal plants from Ghazi Brotha, Attock district. Pak J Bot 20I5;47(I): I I3-20.

20. Saad A, Fadli M, Bouaziz $M$, Benharref A, Mezrioui NE, Hassani L. Anticandidal activity of the essential oils of Thymus maroccanus and Thymus broussonetii and their synergism with amphotericin $B$ and fluconazol. Phytomedicine 2010 Nov; I 7(I 3): I 057-60. DOI: 10.1016/j.phymed.2010.03.020.

2I. Khadir A, Bendahou M, Benbelaid F, 
Abdoune MA, Abdelouahid DE. Antimicrobial power of Thymus lanceolatus Desf. collected in Algeria. Phytothérapie 2013; I I(6): 353-8. DOI: 10.1007/s 10298-0130820-8

22. Sah SN, Regmi S, Tamang MK.
Antibacterial Effects of Thuja Leaves Extract. Int J Applied Sci Biotech (IJASB) 2017 Jun 29;5(2):256-60.

23. Haroun MF, Al-Kayali RS. Synergistic effect of Thymbra spicata L. extracts with antibiotics against multidrug-resistant Staphylococcus aureus and Klebsiella pneumoniae strains. Iran J B a sic Med Sci 2016 Nov; I9(II): II93-1200.

\section{AUTHORS' CONTRIBUTIONS}

Following authors have made substantial contributions to the manuscript as under:

HM, SAT: Concept, acquisition of data, drafting the manuscript, final approval of the version to be published

SHH, SHK: Analysis and interpretation of data, drafting the manuscript, critical review, final approval of the version to be published

AJP, AH: Concept and study design, critical review, final approval of the version to be published

Authors agree to be accountable for all aspects of the work in ensuring that questions related to the accuracy or integrity of any part of the work are appropriately investigated and resolved.

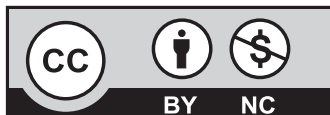

This is an Open Access article distributed under the terms of the Creative Commons Attribution-Non Commercial 2.0 Generic License.

KMUJ web address: www.kmuj.kmu.edu.pk

Email address: kmuj@kmu.edu.pk 